\title{
Immunohistochemical expression and distribution of orexin, orphanin and leptin in the major salivary glands of some mammals
}

\author{
Angelo Leone, Giovanni Francesco Spatola, Daniela Cucco, \\ Vincenzo Tessitore, Giuseppe Bonaventura, Maria Laura Uzzo
}

\author{
Department of Biomedicine and Clinical Neuroscience- BioNec, School of Medicine, \\ Univeristy of Palermo Italy
}

\begin{abstract}
The aim of the study was to determine by immunochemistry the expression of leptin, orexin A and orphanin FQ in the major salivary glands (parotid, submandibular and sublingual) of rat, sheep and cow. These peptides, originally synthesized in central nervous system, adipose tissue and peripheral tissues including gastrointestinal tract, play an orexigenic (orphanin and orexin) or anorexigenic (leptin) roles in the intricate neuronal network appointed to the control of nutritional homeostasis. Peptide-specific immunoreactivity was present in the studied salivary glands with various intensities in different species, in the ductal epithelium, sometimes in the acinar epithelium, and in nervous trunks spread in connective tissue stroma. The obtained data show that salivary glands present an unexpected source of orexigenic and anorexigenic peptides which with their autocrine, paracrine, and endocrine mechanisms of action may participate in the control of salivary gland function. (Folia Histochemica et Cytobiologica 2012, Vol. 50, No. 4, 504-512)
\end{abstract}

Key words: major salivary glands, orphanin FQ, nociception, orexin, leptin, IHC, rat, sheep, cow

\section{Introduction}

It is well known that nutrients' digestion is initiated in the mouth, being under the control of both the major salivary glands, including the parotid, sublingual and submandibular glands, and the minor salivary gland that are scattered into the wall of the oral cavity and oropharyngeal mucosa, which justifies the traditional axiom 'prima digestio fit in ore'.

It has been also classically established that saliva secretion is under the control of the adrenergic and cholinergic branches of the autonomic nervous system [1], which both stimulate salivary secretion.

Experimental data from the last fifteen years have, however, suggested, that the adrenocholinergic control of these organs is also mediated by other neurotransmitters and molecules. E.g. at the end of the

Correspondence address: A. Leone, BioNec. Sezione di Istologia ed Embriologia, Facoltŕ di Medicina e Chirurgia, Via Del Vespro, 12990127 Palermo; tel. +39 09165535 81, fax: +39 09165535 86; e-mail: angelo.leone@unipa.it 90's nitric oxide (NO) was identified acting as a neurotransmitter in many organs [2]. In the salivary glands, NO was shown to be involved not only in the physiological control of secretion, but also in the pathogenesis of many inflammatory and neoplastic processes [3-7].

In addition to NO, we have found recently by immunohistochemistry that rat's major salivary glands express the CB1 receptor for endocannabinoids, which are lipid derivatives involved, among other activities, in nutritional balance $[12,13]$. Continuing our research on these organs, we have investigated the immunohistochemical (IHC) expression and distribution of orphanin FQ, orexin, and leptin, relatively newly-discovered peptides in the major salivary glands of three mammals: cow, sheep and rat. The goal of this study was to provide a morphological basis for the understanding of possible role of these three peptides in the function of major salivary glands.

Orexin A and B (OxA and OxB) and nociceptin/ /orphanin FQ were originally identified in the neurons of the posterolateral hypothalamic and perifornical areas. Therefore, these neuropeptides were con- 
sidered to be exclusively expressed in the Central Nervous System (CNS) [14-16) and responsible for the central regulation of nutritional balance, relaying orexigenic effects after activation of their receptors Ox1R and Ox2R for the orexin, and ORL-1 for nociceptin/orphanin FQ $[17,18]$. Further immunohistochemical studies identified the presence of these neuropeptides in peripheral organs and tissues associated with the energy balance such as the gastrointestinal tract and pancreas [19-22].

Leptin is being considered as the typical hormone with anorectic action, hence its name of 'satiety hormone'. It was identified for the first time in white and brown adipose tissue, and then in many other cells, including chief cells in human oxyntic glands [23-25] and gastroenteropancreatic system (GEP) of Zucker rats. Further unexpected localization of these three mediators of energy balance in other areas which are not associated with the regulation of energy metabolism, such as the urogenital $[26,27]$ and respiratory systems, adrenal glands [28] and testis [29], suggest new functional roles performed by these peptides.

\section{Material and methods}

Animals and tissue preparation. 10 Wistar rats treated in accordance with the Helsinki Convention on the use of animals in biomedical research were used. The animals were sacrificed after anesthesia $(50 \mathrm{mg} / \mathrm{kg}$ Nembutal administered peritoneally). Also 5 cows and 5 sheeps collected from beef abattoir were used. From all animals parotid, submandibular and sublingual salivary glands were taken. The tissues were fixed in $10 \%$ buffered formalin and after 12-24 hours depending on the size of the sample were washed in water, then dehydrated in alcohol at increasing concentrations, cleared in xylene and embedded in paraffin. The samples were sectioned and processed for immunohistochemistry using antibodies against leptin, orexin A, orphanin FQ; the reactions were revealed using detection kit En Vision + + System-HRP with AEC as substrate (Dako, Italy).

Immunohistochemistry. Serial sections $8 \mu \mathrm{m}$ thick were cut on Leica microtome RM2145, dried overnight at $37^{\circ} \mathrm{C}$ and then stored at room temperature. The day after, the slides were dewaxed and re-hydrated by sequential immersion in a graded series of alcohols and transferred into water for 5 min; to inhibit any endogenous peroxidase activity the slides were treated for five minutes with Peroxidase Block (Dako). Subsequently, the slides were transferred into PBS (Phosphate-Buffered Saline, $\mathrm{pH}$ 7.4) at room temperature. The following protocol was realized using the kit En-Vision + + System HRP with AEC as substrate (Dako). After rinsing with PBS for $4 \mathrm{~min}$, the sections were incubated overnight at $4^{\circ} \mathrm{C}$ with polyclonal anti- leptin anhtibody(Ob A-20, Santa Cruz Biotechnology, Inc.) diluted 1:100; polyclonal anti- orphanin FQ antibody (Gene Tex, Inc.) diluted 1:500; polyclonal anti-orexin A antibody (Chemicon) diluted 1:100. After the incubation, any excess antibody was removed by washing with PBS for 5 minutes. Next, the sections were incubated with Peroxidase labeled polymer conjugated to goat anti-rabbit immunoglobulin in Tris-HCl buffer containing stabilizing protein and an antimicrobial agent. Unbound polymer was removed by washing ( 2 times with PBS, 5 minutes each) and subsequently AEC chromogen in substrate buffer was added, and washed after 5 minutes with distilled water. Slides were coverslipped with one drop of an aqueous mounting medium (Dako).

Negative controls were performed by omission of primary antibody, and by incubating sections with antiserum saturated with homologous antigen.

The IHC technique was standardized according to the suggestions of the US Biological Stain Commission [35].

Image analysis. The IHC specimens were examined using a Leica Laborlux S Microscope (Leica Microsystem GmbH Wetzlar, Germany) with a Nikon DSL2 photo digital system (Nikon Corp. Tokyo, Japan). Each sample was analyzed with a double-blind system and two different operators. Moreover, the results were compared to an image analysis obtained from digital TIF files acquired with the multispectral system [31, 32]. To apply this method, we made sequential shots using CoKin (Cokin SAS, Rungis Cedex, France) filters to obtain all the different color spectra. Adobe Photoshop CS4 extended (Adobe Systems Inc, San Jose, CA) was used to elaborate images $[32,33]$. Choosing the spectrum related to AEC, we converted the image color profile from RGB to CMYK. Then we chose the yellow channel because it was found to have the best linear response to color intensity and thus to protein presence [34]. The quantification of IHC staining was performed by using a score system with values from $1+$ to $5+$ [34-36].

\section{Results}

The major salivary glands (parotid, submandibular and sublingual) in the examined mammals were tubulo-acinar structures. The ductal system was composed of intralobular ducts (intercalated and striated ducts) and excretory interlobular ducts. The secretory parenchyma (acini) contained only serous cells in the parotid gland or mucous and serous cells in the submandibular and sublingual glands. All the results obtained have been resumed in Table 1 .

\section{Parotid glands}

In cow, peptidergic IHC reactivity was widely distributed in the cytoplasm of intralobular ductal epithelial cells with variable intensity for each peptide (Table 1). Within the same cell type, the immunoreactivity was 


\begin{tabular}{|c|c|c|c|c|c|c|c|c|c|}
\hline \multirow{4}{*}{ 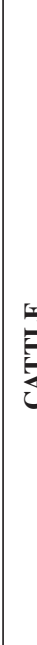 } & 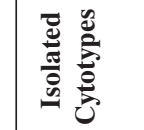 & $\begin{array}{l}+ \\
+ \\
+ \\
+ \\
+\end{array}$ & 1 & 1 & \multirow{4}{*}{ 稳 } & 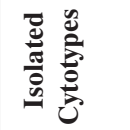 & 1 & I & 1 \\
\hline & 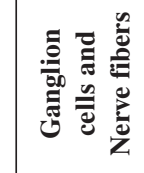 & 0 & 1 & 1 & & 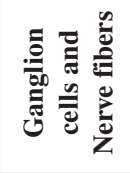 & 0 & $\begin{array}{l}+ \\
+\end{array}$ & $\begin{array}{l}+ \\
+ \\
+\end{array}$ \\
\hline & |言总 & 0 & 0 & 0 & & 尝言竞 & + & + & + \\
\hline & 豆 & $\stackrel{+}{+}$ & $\begin{array}{l}+ \\
+ \\
+\end{array}$ & $\begin{array}{l}+ \\
+ \\
+\end{array}$ & & 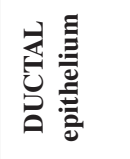 & $\stackrel{+}{+}$ & $\stackrel{+}{+}$ & $\stackrel{+}{+}$ \\
\hline \multirow{4}{*}{ 武 } & 总 & $\begin{array}{l}+ \\
+ \\
+\end{array}$ & 1 & 1 & \multirow{4}{*}{ 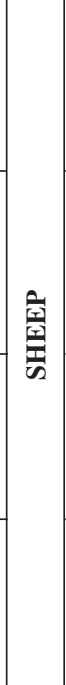 } & 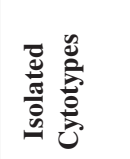 & $\begin{array}{l}+ \\
+ \\
+ \\
+\end{array}$ & $\begin{array}{l}+ \\
+ \\
+ \\
+\end{array}$ & $\begin{array}{l}+ \\
+ \\
+ \\
+\end{array}$ \\
\hline & 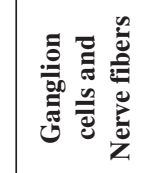 & 0 & $\stackrel{+}{+}$ & $\stackrel{+}{+}$ & & 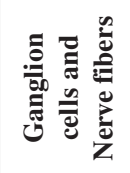 & 0 & $\begin{array}{l}+ \\
+ \\
+ \\
+ \\
+\end{array}$ & $\begin{array}{l}+ \\
+ \\
+ \\
+ \\
+\end{array}$ \\
\hline & 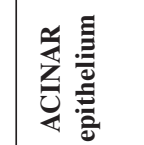 & + & + & + & & 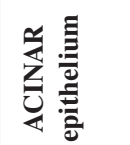 & 0 & 0 & 0 \\
\hline & 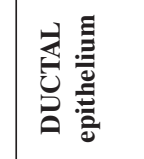 & $\stackrel{+}{+}$ & + & + & & 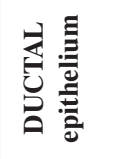 & 0 & 0 & 0 \\
\hline \multirow{4}{*}{$\stackrel{5}{\Omega}$} & 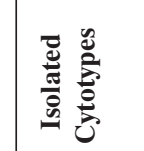 & 1 & 1 & 1 & \multirow{4}{*}{$\frac{5}{q}$} & 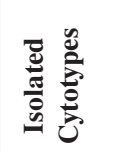 & 1 & 1 & 1 \\
\hline & 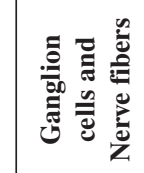 & 0 & $\begin{array}{l}+ \\
+ \\
+ \\
+\end{array}$ & $\begin{array}{l}+ \\
+ \\
+\end{array}$ & & 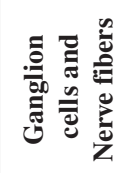 & 1 & $\begin{array}{l}+ \\
+ \\
+ \\
+ \\
+\end{array}$ & I \\
\hline & 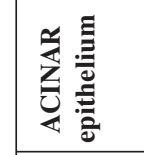 & 0 & 0 & 0 & & 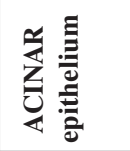 & 0 & 0 & 0 \\
\hline & 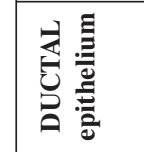 & $\stackrel{+}{+}$ & $\begin{array}{l}+ \\
+ \\
+ \\
+ \\
+\end{array}$ & + & & 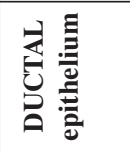 & $\begin{array}{l}+ \\
+ \\
+ \\
+\end{array}$ & $\begin{array}{l}+ \\
+ \\
+ \\
+\end{array}$ & $\begin{array}{l}+ \\
+ \\
+ \\
+\end{array}$ \\
\hline \multicolumn{2}{|c|}{ تَّت } & 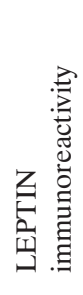 & 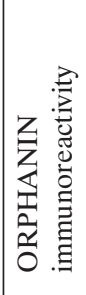 & 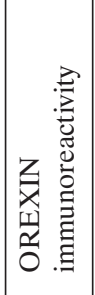 & \multicolumn{2}{|l|}{ 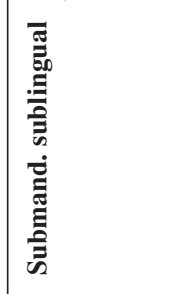 } & 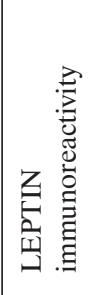 & 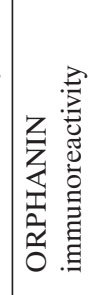 & 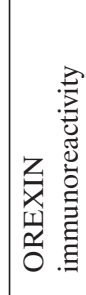 \\
\hline
\end{tabular}


not always distributed with the same intensity in all cells, and it appeared not uniformly homogeneous (Figure 1). Sometimes leptin immunoreactivity was, mostly in the microgranular form, detectable in isolated prismatic cell types (Figure 2) that showed distinct fluorescence by multispectral analysis. The serous acinar compartment appeared to be not labelled.

In rat, the orphaninergic immunoreactivity was present almost uniformly in the ductal epithelium which was intensely immunoreactive (Figure 3); the ductal leptin immunoreactivity was less uniform and the orexinergic immunoreactivity was weak and often limited to the basal edge of the ductal sialocytes (Figure 4). In the connective tissue stroma orphaninergic and orexinergic immunoreactivity was found in nervous fibers (Figures 5-6). The serous acinar compartment was immunohistochemically not labelled.

In sheep, the ductal epithelium exhibited leptin immunoreactivity only in a few ductal sialocytes (Figures 7-8) which was clearly evident at multispectral analysis. In the ductal epithelium, orphaninergic and orexinergic immunoreactivity was very weak, however, it increased at the apical edge of sialocytes (Figure 9). Orexinergic nervous fibers were found in the connective tissue stroma. The acinar compartment exhibited discrete immunoreactivity.

\section{Submandibular and sublingual glands}

The results obtained for the submandibular and sublingual glands have been described together as the immunostained structures were similar in both glands.

In cow, ductal peptidergic immunoreactivity was found in sialocytes, it was sometimes unevenly distributed (Table 1). Serous acini exhibited a modest peptidergic immunoreactivity that increased in small acini located close to the ductal branching (Figure 10). In the periductal stromal connective tissue small orexinergic gangliar cells and fibers were frequently found; orphaninergic gangliar cells and fibers were also found in some areas of the stroma (Figure 11).

In rat, the peptidergic immunoreactivity of all neuropeptides studied of the ductal epithelium was fairly uniform (Table 1, Figure 12).

In sheep, the peptidergic immunoreactivity of the ductal epithelium was not homogeneous. The serous acinar compartment did not exibit peptidergic immunoreactivity.

In rat and sheep, the periductal and perivascular connective tissue contained orphaninergic ganglion neurons (Figure 13). In addition, in intercalated ducts, some cells, irregularly scattered among unreactive epithelial mucous cells, showed peptidergic immunoreactivity (Figures 14-15). Finally peptidergic immunoreac-

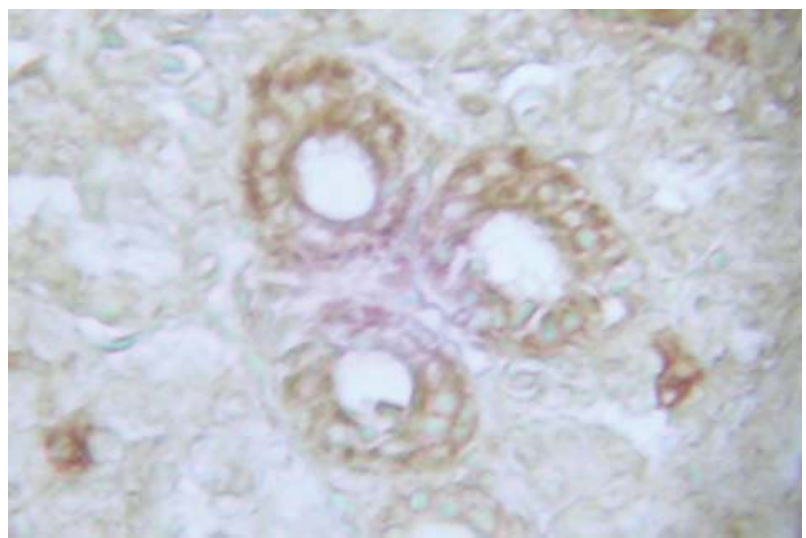

Figure 1. Cow parotid gland: Leptin immunoreactivity (Ir) of ductal epithelium. Magnification of objective $20 \times$

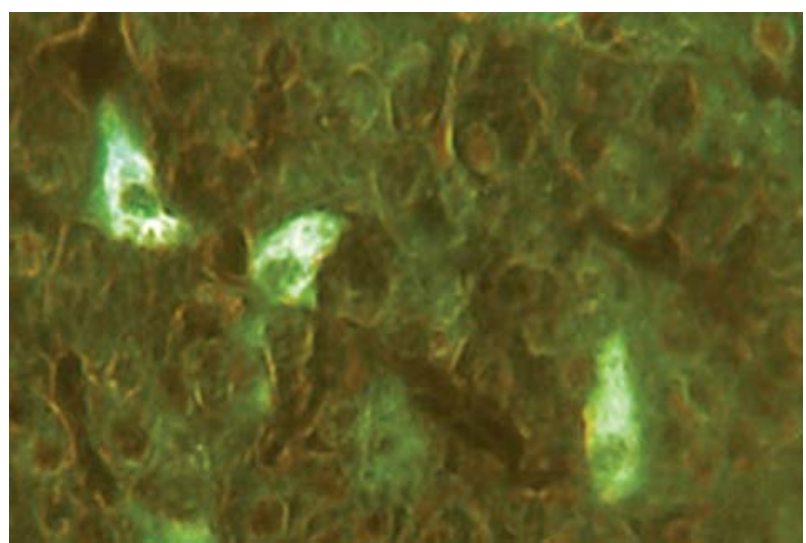

Figure 2. Cow parotid gland: Leptin Ir in some cells. Lack of immunoreactivity in serous acini. Multispectral analysis. $40 \times$

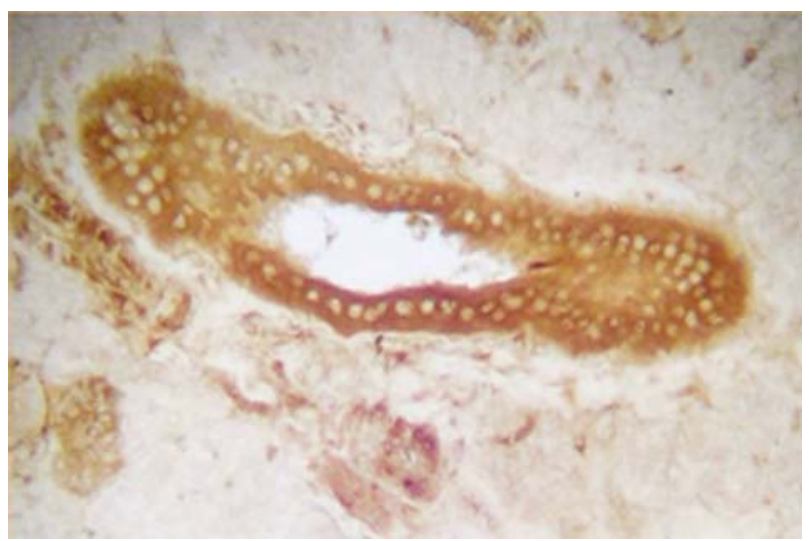

Figure 3. Rat parotid gland: evenly distributed orphanin Ir of ductal ephitelium. $20 \times$

tivity, often in the microgranular form, was displayed by small cells, probably basket cells, that were located between the glandular cells and basal lamina (Figure 16). 


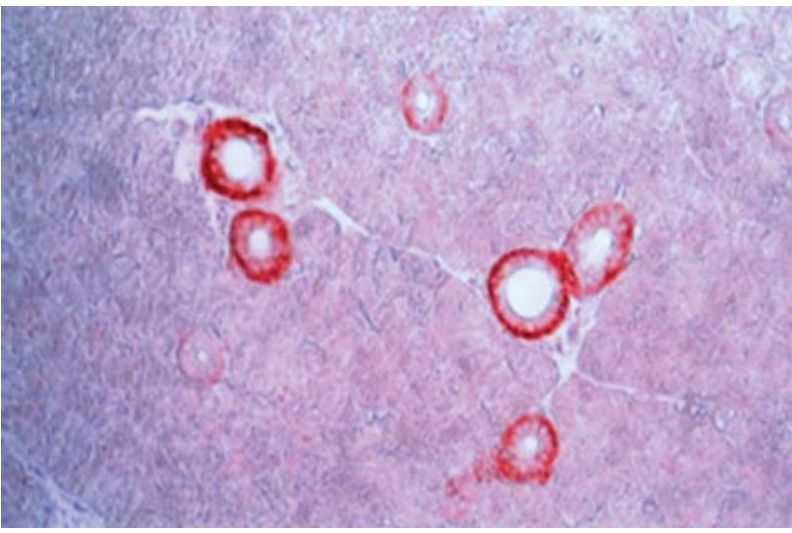

Figure 4. Rat parotid gland: orexin Ir in ductal sialocytes' basal cytoplasm. No Ir in acinar parenchyma. $10 \times$

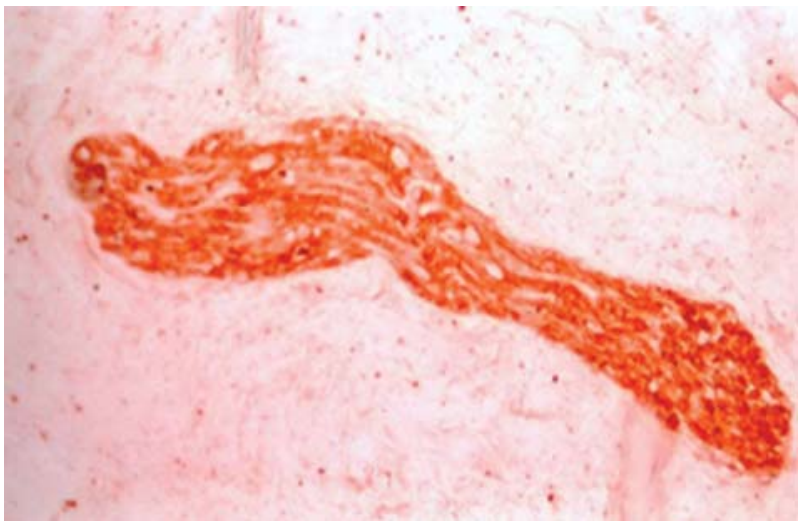

Figure 5. Rat parotid gland: orphanin Ir in nerve fibers. $40 \times$

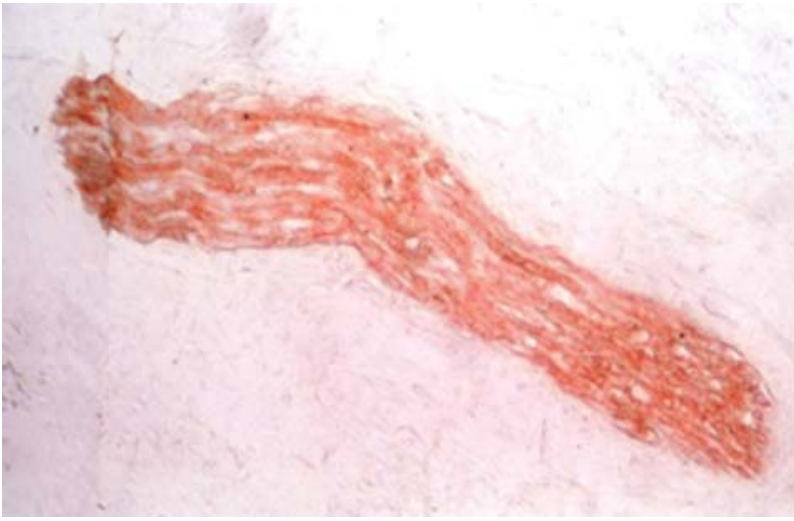

Figure 6. Rat parotid gland: orexin Ir in nerve fibers. $40 \times$

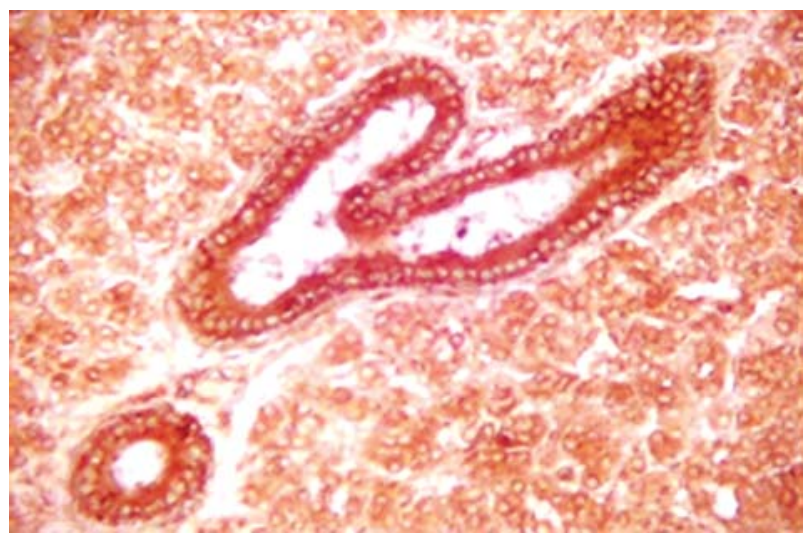

Figure 7. Sheep parotid gland: discrete leptin Ir of ductal epithelium. Weak Ir in acinar compartment. $20 \times$

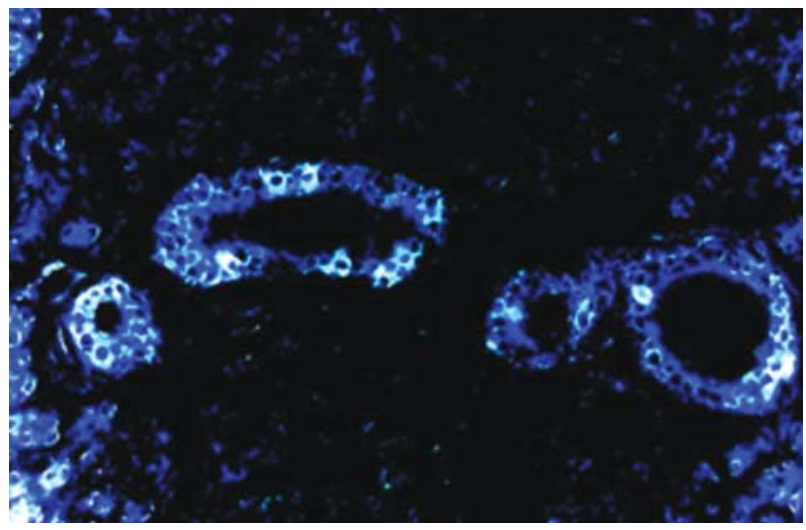

Figure 8. Sheep parotid gland: leptin Ir of some ductal sialocytes at multispectral analysis. $10 \times$

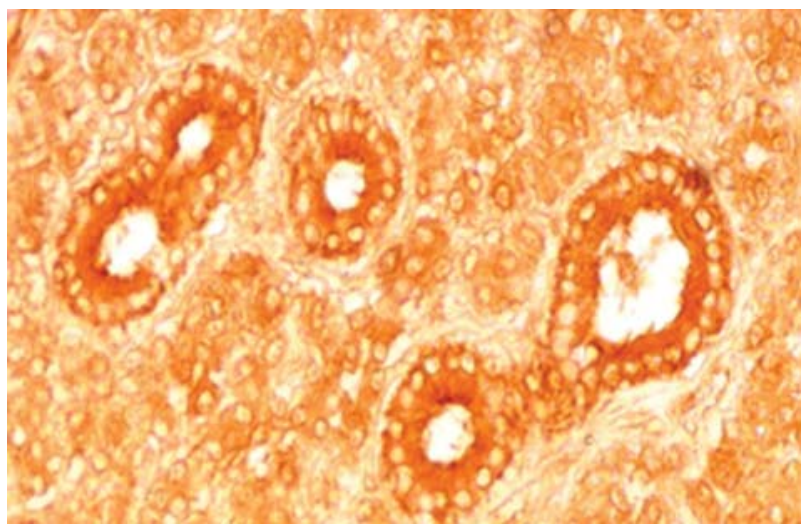

Figure 9. Sheep parotid gland: Intense orexin Ir at the apical pole of ductal sialocytes. Weakly reactive acinar parenchyma. $20 \times$ 


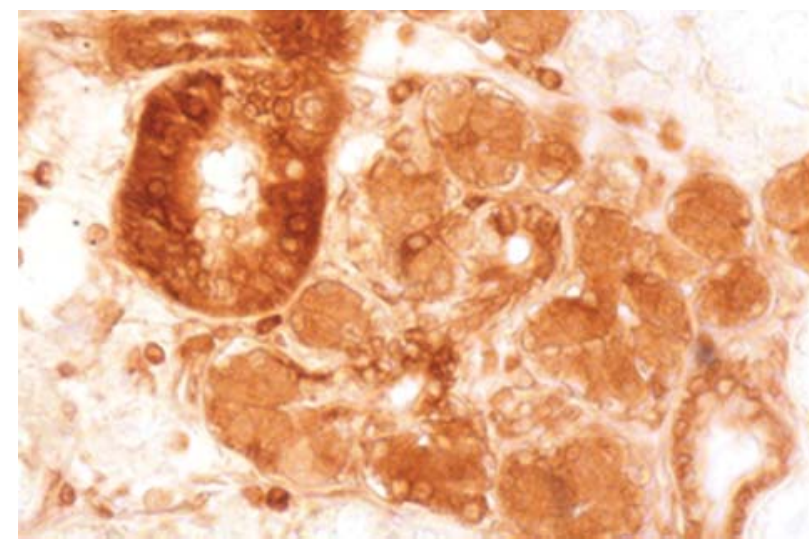

Figure 10. Cow sublingual gland: orphanin Ir in periductal serous acini. $40 \times$

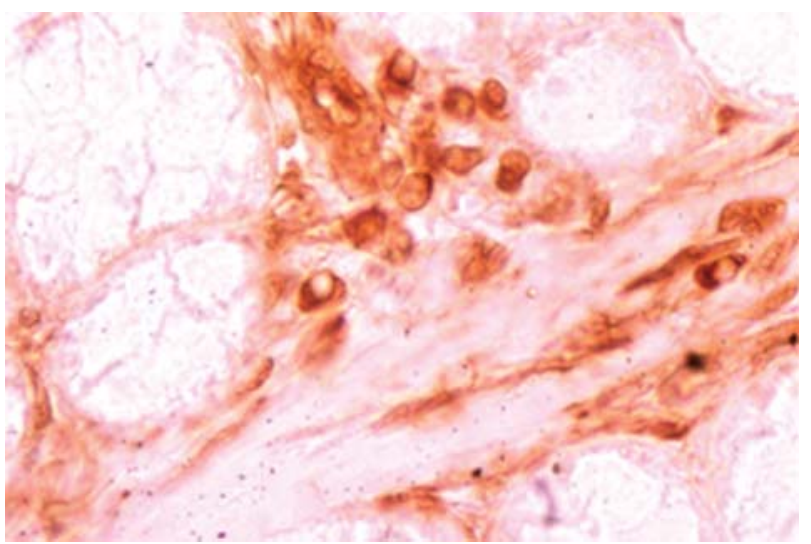

Figure 11. Cow sublingual gland: orexin Ir in stromal cells. $63 \times$

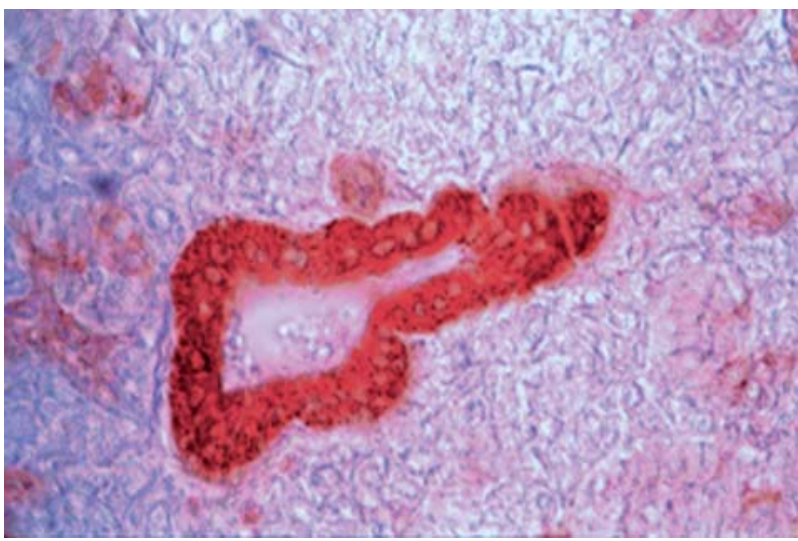

Figure 12. Rat sublingual gland: orexin Ir of ductal epithelium. $20 \times$

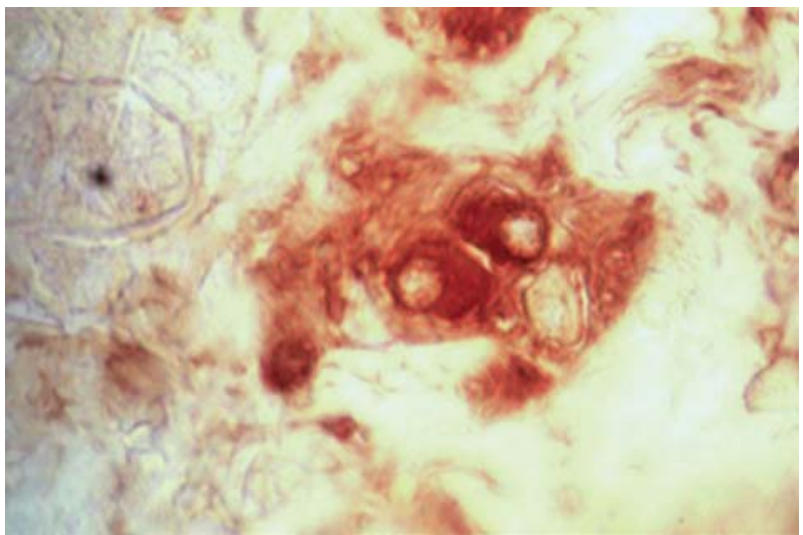

Figure 13. Rat sublingual gland: orphanin Ir of stromal gangliar body nerve cells. $63 \times$

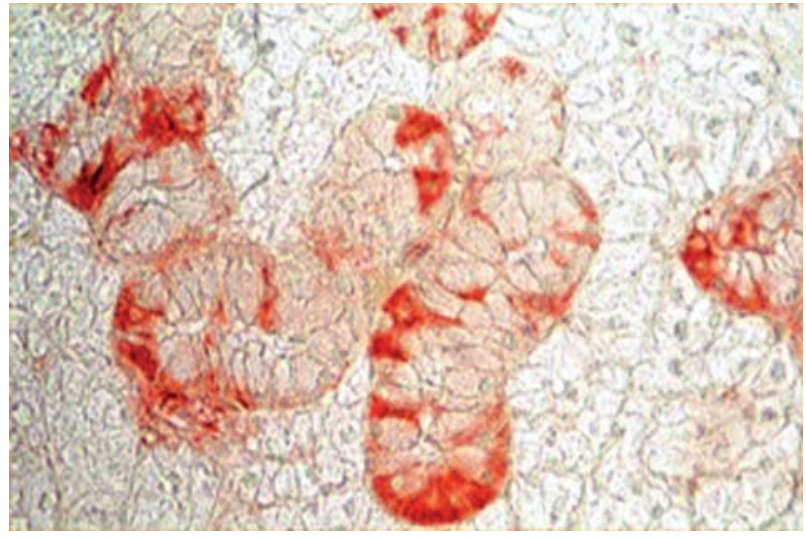

Figure 14. Rat submandibular gland: orexin Ir of some cells irregulary scattered among unreactive epithelial mucous cells in intercalated ducts. $40 \times$

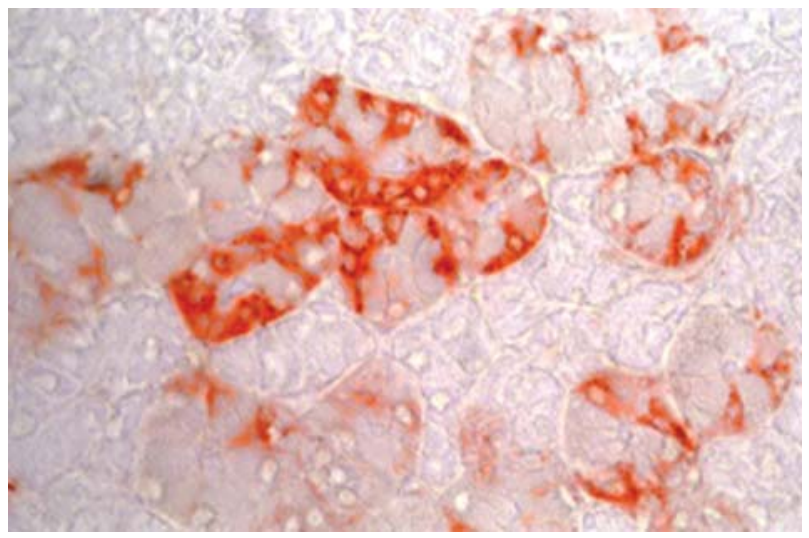

Figure 15. Rat submandibular gland: orexin Ir of some cells irregulary scattered among unreactive epithelial mucous cells in intercalated ducts $40 \times$ 


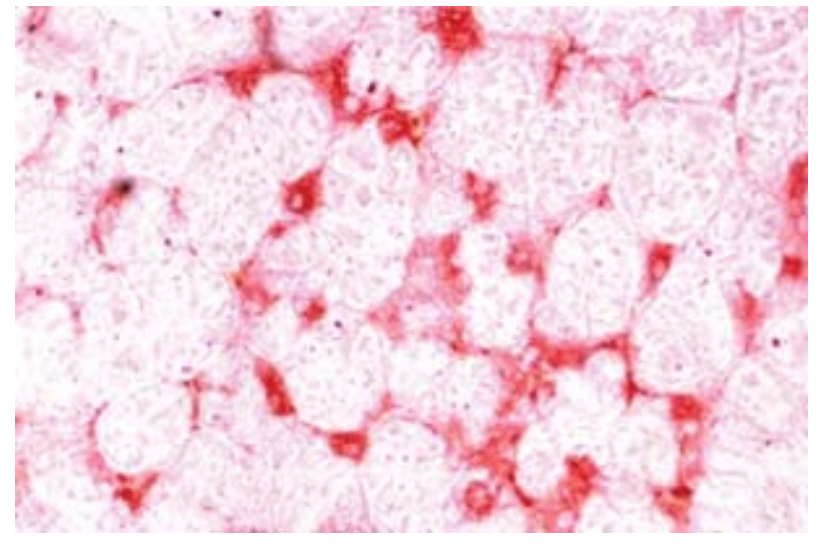

Figure 16. Rat sublingual gland: orexin Ir in some interacinar. cells $40 \times$

\section{Discussion}

Previous research by other authors[8-11] demonstrated that the major salivary glands produce in humans such hormones as insulin, glucagon, leptin and ghrelin. We have extended immunohistochemical peptidergic mapping to the major salivary glands of three mammal species, cow, sheep and rat, documenting the presence of leptin, nociception/orphanin FQ and orexin. Our results show that these organs represent yet an another organ exhibiting these peptides, alongside the gastrointestinal tract, adipose tissue and skeletal muscles.

It is not easy to assign a functional role to the presence of the appetite-regulating peptides detected in the salivary glands, because neuropeptides derive from the proteolysis of giant precursors (prepro-orexin, prepro-orphanin). In attributing a possible role to the detected peptides, one should consider the orexinergic or anorexinergic activities traditionally attributed to these peptides in the regulation of appetite and energy regulation, acting as hunger (orphanin and orexin) or satiety (leptin) signals.

In making a final assessment on the peptidergic immunoreactivity in the tested animal species it should be pointed out that the immunohistochemical distribution of examined peptides in the three major salivary glands was essentially limited to the ductal system in its various segments (interlobular, intralobular, striated and intercalated ducts). Serous acini were weakly or non-immunoreactive. Regardless of the varying intensity of the IHC signal detected in the different animal species studied, we found that in the same species a variety of structural components were immunopositive (ductal epithelia, isolated sialocytes, nervous cells and nerve fibers). Altogether, these data suggest that the examined peptides may play various roles in functions of salivary glands.
The immunoreactivity detected mainly in the ductal system, strongly suggests that the examined peptides do not control the first step of the classic secretory process by acinar glandular cells but rather control the special functions of ductal sialocytes, involved not only in the transport of the saliva but also in the modification of the primary saliva secreted by the acini through electrolyte reabsorption and protein production [37-41]. Previous studies identified presence of leptin receptor in sialocytes of the human ductal system $[10,43]$, suggesting that leptin may exert control of salivary function. Our findings together with the identification of leptin in human saliva [11, 42], suggest that salivary leptin derives not only from blood but also from ductul cells of salivary glands.

In cow and rat, the expression of orphanin FQ and orexin in nerves and gangliar cells suggests a role of those neuropeptides in controlling salivary gland function similarly to the classical adrenergic, cholinergic and nitroxidergic innervation.

The leptin and orphanin FQ immunoreactivity found in isolated cells in cow parotid gland (stroma and acini) and in small cells in rat intercalated ducts among mucous negative sialocytes, might be related to the endocrine activity of these peptides. Therefore co-existence of endocrine and exocrine cells in an organ traditionally considered exclusively exocrine, should now be considered. The exocrine glands of the gastrointestinal tract comprise many cells of the Diffuse Neuroendocrine System (DNES), and our findings provide evidence that also major salivary glands contain DNES cells.

Our findings may be also related to the recent studies on a possible role of 'neither-anorexigenic nororexigenic'peptides' which may function as growth factors regulating the proliferation of specific cell types in various organs [45-51]. In this context the observation that proliferation of sialocytes was reduced in the presence of recombinant leptin [44] seems noteworthy. However, additional studies are necessary to check if the presence of orexin, orphanin FQ and leptin in the major mammalian salivary glands, documented in our present study, may affect physiology and pathophysiology of these organs.

\section{References}

1. Luo W, Latchney LR, Culp DJ. G protein coupling to M1 and M3 receptors in sublingual glands. Am J Physiol Cell Physiol. 2001;280:884-896.

2. Bredt DS, Snyder SH, Nitric oxyde, a novel neuronal messenger. Neuron. 1992;8:3.

3. Lohinai Z, Szekely AD, Soos L, Feher E. Distribution of nitric oxide synthase containing elements in the feline submandibular gland. Neurosci Lett. 1995;192:9-12.

4. Soinila S, Vanhatalo S, Lumme A, Back N, Soinila J. Nitric oxide synthase in the autonomic and sensory ganglia inner- 
vating the submandibular salivary gland. Microsc Res Techn 1996;35:32-43.

5. Lomniczi A, Suburo AM, Elverdin JC et al. Role of nitric oxide in salivary secretion. Neuroimmunomodulation. 1998;5:226-233.

6. Takai N, Uchihashi K, Higuchi K, Yoshida Y, Yamaguchi M. Localization of neuronal-costitutive nitric oxide synthase and secretory regulation by nitric oxide in the rat submandibular and sublingual glands. Arch Oral Biol. 1999;44:745-750.

7. Looms D, Tritsaris K, Pedersen AM, Nauntofte B, Dissing S. Nitric oxide signalling in salivary glands. J. Oral Pathol Med. 2002:31:569-584.

8. Egea JC, Hirtz C, Gross R et al. Preproinsulin I and II mRNA expression in adult rat submandibular glands. Eur J Oral Sci. 2000;108:292-296.

9. Perez-Castillo A, Blazquez E. Synthesis and release of glucagon by human glands. Diabetologia. 1980;19:123-129.

10. De Matteis R, Puxeddu R, Riva A, Cinti S. Intralobular ducts of human major salivary glands contain leptin and its receptor. J Anat. 2002;201:363-370.

11. Aydin S, Halifeoglu I, Ozercan IH et al. A comparison of leptin and gherlin levels in plasma and saliva of young healthy subjects. Peptides. 2005;26:647-652.

12. Di Marzo V, Matias I. Endocannabinoid control of food intake and energy balance. Nat Neurosci. 2005;8: 85-89.

13. Cota D, Woods SC. The role of the endocannabinoid system in the regulation of energy homeostasis. Curr Opin Endocrin Diab. 2005;12,338-351.

14. De Lecea L, Kilduff TS, Peyron C et al. The hypocretins: hipotalamus-specific peptides with neuroexcitatory activity. Proc Natl Acad Sci USA; 1998;95:322-327.

15. Peyron C, Tighe DK, Van den Pol AN et al. Neurons containing hypocretin (orexin) project to multiple neuronal systems. J Neurosci, 1998;18: 9996-10015.

16. Neal CR Jr, Mansour A, Reinscheid R, Nothacker HP, Civelli O, Watson SJ Jr. Localization of orphanin FQ ( nociceptin ) peptide and messenger RNA in the central nervous system of the rat. J Comp Neurol. 19; 1999;406:503-547.

17. Meunier JC, Mollereau C, Toll L et al. Isolation and structure of the endogenous agonist of opioid receptor-like ORL1 receptor. Nature. 1995;377:532-535.

18. Sakurai T, Amemiya A, Ishii $M$ et al. Orexin and orexin receptors: a family of hypothalamic neuropeptides and $\mathrm{G}$ protein-coupled receptors that regulate feeding behavior. Cell. 1998;92:573-585.

19. Annette L, Kirchgessner AL. Orexins in the Brain-Gut Axis. Endocrine Rev. 2002;23:1-15.

20. Adeghate E, Hameed RS. Immunolocalization of orexin -1 receptor in the pancreas of normal and diabetic rats. Biogenic Amines. 2005;19:347-355.

21. Dall'Aglio C, Pascucci L, Mercati F, Giontella A, Pedini V, Ceccarelli P. Immunohistochemical identification and localization of orexin A and orexin type2 receptor in the cow gastrointestinal tract. Res Vet Sci. 2009;86:189-193.

22. Adeghate E, Fernandez-Cabezudo M, Hameed R et al. Orexin1 Receptor colocalizes with pancreatic hormones in islet cells and modulates the outcome of streptozotocin-induced diabetes mellitus. PloS One. 2010;5:8587.

23. Cinti S, Frederic RC, Zingaretti MC, De Matteis R, Flier JS, Lowell BB. Immunohistochemical localization of leptin and uncoupling protein in white and brown adipose tissue. Endocrinology. 1997;138,797-804.

24. Bado A, Lavasseur S, Attoub S et al. The stomach is a source of leptin. Nature. 1998;394:790-793.
25. Cinti S, De Matteis R, Pico C et al. Secretory granules of endocrine and chief cells of human stomach mucosa contain leptin. Int J Obes. 2000;24:789-793.

26. Karteris E, Chen J, Randeva HS. Expression of human prepro-orexin and signaling characteristics of orexin receptors in the male reproductive system. J Clin Endocrinol Metab. 2004;89:1957-1962.

27. Pavone LM, Tafuri S, Avallone L, Staiano N, Vittoria A, Expression of orexin A and its receptor 1 in the vestibular glands of the cow genital tract. Anat Rec. 2009;292:202-206.

28. Randeva HS, Karteris E, Grammatopoulos D, Hillhouse EW. Expression of orexin A and the functional orexin type2 receptors in the human adult adrenals: implications for adrenal function and energy homeostasis. J Clin Endocrinol Metab. 2001;86:4808-4813.

29. Barreiro ML, Pineda R, Gaytan F et al. Pattern of orexin expression and direct biological actions of orexin-A in rat testis. Endocrinology. 2005;146:5164-5175.

30. Walker RA. Quantification of immunohistochemistry - issues concerning methods, utility and semiquantitative assessment I. Histopathology. 2006;49:406-410.

31. Taylor CR, Levenson RM. Quantification of immunohistochemistry - issues concerning methods, utility and semiquantitative assessment II. Histopathology. 2006;49:411-424.

32. Lehr HA, Mankoff DA, Corwin D, Santeusanio G, Gown AM. Application of photoshop-based image analysis to quantification of hormone receptor expression in breast cancer. J Histochem Cytochem. 1997;45:1559-1565.

33. Kirkeby S, Thomsen CE. Quantitative immunohistochemistry of fluorescence labelled probes using low-cost software. J Immunol Meth. 2005;301:102-113.

34. Pham NA, Morrison A, Schwock J et al. Quantitative image analysis of immunohistochemical stains using a CMYK color model. Diagn Pathol. 2007;27:8.

35. Skaland I, Ovestad I, Janssen EA et al. Digital image analysis improves the quality of subjective HER-2 expression scoring in breast cancer. Appl Immunohistochem Mol Morphol. 2008; 16:185-190.

36. Skaland I, Řvestad I, Janssen EA et al. Comparing subjective and digital image analysis HER2/neu expression scores with conventional and modified FISH scores in breast cancer. J Clin Pathol. 2008;61:68-71.

37. Riva A, Testa-Riva F, Del Fiacco M, Lantini MS. Fine structure and cytochemistry of the intralobular ducts of the human parotid gland. J Anat. 1976;122:627-640.

38. Testa-Riva F. Ultrastructure of human submandibular gland. J. Submicr. Cytol. 1977;9:251-266.

39. Young JA, Van Lennep EW. Transport of salt in salivary glands. In: Giebisch G, Tosteson DC, Ussing HH eds. Membrane Transport in Biology. Berlin, Springer Verlag; 1979:4B563-674.

40. Lantini MS, Cossu M. Immunohistochemical investigation of the subcellular distribution of some secretory products in human salivary glands. Eur J Morph. 1998;36:230-234.

41. Tandler B, Phillips CJ. Organic secretion by striated ducts. Eur J Morph. 2000;38:233-236.

42. Groschl M, Rauh M, Wagner R et al. Identification of leptin in Human Saliva. J Clin Endocrinol Metab. 2001;86:5232-5239.

43. Bohlender J, Rauh M, Zenk J, Groschl M. Differential distribution and expression of leptin and expression of leptin and the functional leptin receptor in major salivary glands of humans. J Endocrinol. 2003;178:217-223.

44. Higa M, Shimabukuro M, Fukuchi M, Komiya I, Takasu N. Atrophic change of rat salivary gland during adenovirus- 
-induced hiperleptinemia. Biochem. Biophys. Res. Commun 2002;291:675-679.

45. Wolf G, Hamman A, Han DC. et al. Leptin stimulates proliferation and TGF-B expression in renal glomerular endothelial cells: Potential role in glomerulosclerosis. Kidney Int 1999;860-872.

46. Tsuchiya T, Shimizu H, Horie T, Mori M. Expression of leptin receptor in lung: leptin as a growth factor. Eur J Pharmacol. 1999;365:273-279.

47. Zwirska-Korczala K, Adamczyk-Sowa M, Sowa P. et al. Role of leptin, ghrelin, angiotensin II and orexins in 3T3 L1 preadipocyte cells proliferation and oxidative metabolism. J Physiol Pharmacol. 2007;58(Suppl. 1):53-64.
48. Easten K H, Harry R A, Purcell W M, McLeod D. Nociceptin-induced modulation of human T cell function. Peptides 2009;30:926-934.

49. Ko MH, Kim YH, Woo RS, Kim KW. Quantitative analysis of nociceptin in blood of patients with acute and chronic pain. Neuroreport. 2002;13:1631-1633.

50. Trombella S, Vergura R, Falzarano S, Guerrini R, Calo G, Spisani S. Nociceptin/orphanin FQ stimulates human monocyte chemotaxis via NOP receptor activation. Peptides. 2005;26:1497-1502.

51. Waits PS, Purcell WM, Fulford AJ MecLeod JD. Nociceptin/ /orphanin FQ modulates human T cell function in vitro. J Neuroimmunol. 2004;149:110-120.

Submitted: 18 November, 2011 Accepted after reviews: 21 November, 2012 